\title{
Flux measurements by the NRC Twin Otter atmospheric research aircraft: 1987-2011
}

\author{
Raymond L. Desjardins ${ }^{1}$, Devon E. Worth ${ }^{1}$, J. Ian MacPherson ${ }^{2}$, Matthew Bastian ${ }^{2}$, and \\ Ramesh Srinivasan ${ }^{2}$ \\ ${ }^{1}$ Science and Technology Branch, Agriculture and Agri-Food Canada, Ottawa, Ontario, Canada \\ ${ }^{2}$ National Research Council of Canada, Aerospace, Flight Research Laboratory, Ottawa, Ontario, Canada \\ Correspondence to: Raymond L. Desjardins (ray.desjardins@agr.gc.ca)
}

Received: 14 December 2015 - Revised: 22 February 2016 - Accepted: 29 February 2016 - Published: 30 March 2016

\begin{abstract}
Over the past 30 years, the Canadian Twin Otter research group has operated an aircraft platform for the study of atmospheric greenhouse gas fluxes (carbon dioxide, ozone, nitrous oxide and methane) and energy exchange (latent and sensible heat) over a wide range of terrestrial ecosystems in North America. Some of the acquired data from these projects have now been archived at the Flight Research Laboratory and Agriculture and Agri-Food Canada. The dataset, which contains the measurements obtained in eight projects from 1987 to 2011 are now publicly available. All these projects were carried out in order to improve our understanding of the biophysical controls acting on land-surface atmosphere fluxes. Some of the projects also attempted to quantify the impacts of agroecosystems on the environment. To provide information on the data available, we briefly describe each project and some of the key findings by referring to previously published relevant work. As new flux analysis techniques are being developed, we are confident that much additional information can be extracted from this unique data set.
\end{abstract}

\section{Introduction}

For over three decades, the National Research Council of Canada (NRC) Twin Otter atmospheric research aircraft has been involved in projects associated with the exchange of energy and trace gases between the biosphere and the atmosphere (MacPherson and Bastian, 2003; Desjardins et al., 1982). These studies have focussed on quantifying atmosphere-biosphere interactions as well as quantifying greenhouse gas (GHG) emissions from agroecosystems. The aircraft has been flown in a number of national and international projects involving a large number of collaborators from university and government research organizations (Pederson et al., 1995; Sellers et al., 1992, 1997; Stewart et al., 1998; Kustas et al., 2005; Jackson et al., 1999). Most of the data from these flux projects have been reorganized to a common format and stored in digital form (MacPherson and Bastian, 2003). The purpose of this publication is to provide information on the data that are available and briefly mention some of the interesting results that have been obtained in order to promote further use of these data. In the near future, these data will be transferred to the Government of Canada open data portal (www.open.canada.ca), where they will be downloadable by the public, free of charge. The use of the data will be subject to the Open Government License. We encourage researchers who are interested in analyzing aircraftbased flux data to contact the authors.

\section{Aircraft-based flux measurements}

The NRC Twin Otter atmospheric research aircraft (Fig. 1) has been instrumented to accurately measure the three components of atmospheric motion and the vertical fluxes of heat, momentum, water vapour, carbon dioxide $\left(\mathrm{CO}_{2}\right)$, ozone $\left(\mathrm{O}_{3}\right)$, methane $\left(\mathrm{CH}_{4}\right)$ and nitrous oxide $\left(\mathrm{N}_{2} \mathrm{O}\right)$, as well as other supporting meteorological and spectral data (Desjardins and MacPherson, 1991; Desjardins et al., 2000). Since one of the aircraft's primary research roles is in the field of land/atmosphere interactions, a number of remote sensing instruments were used to document surface conditions during flux-measuring campaigns. For several research 


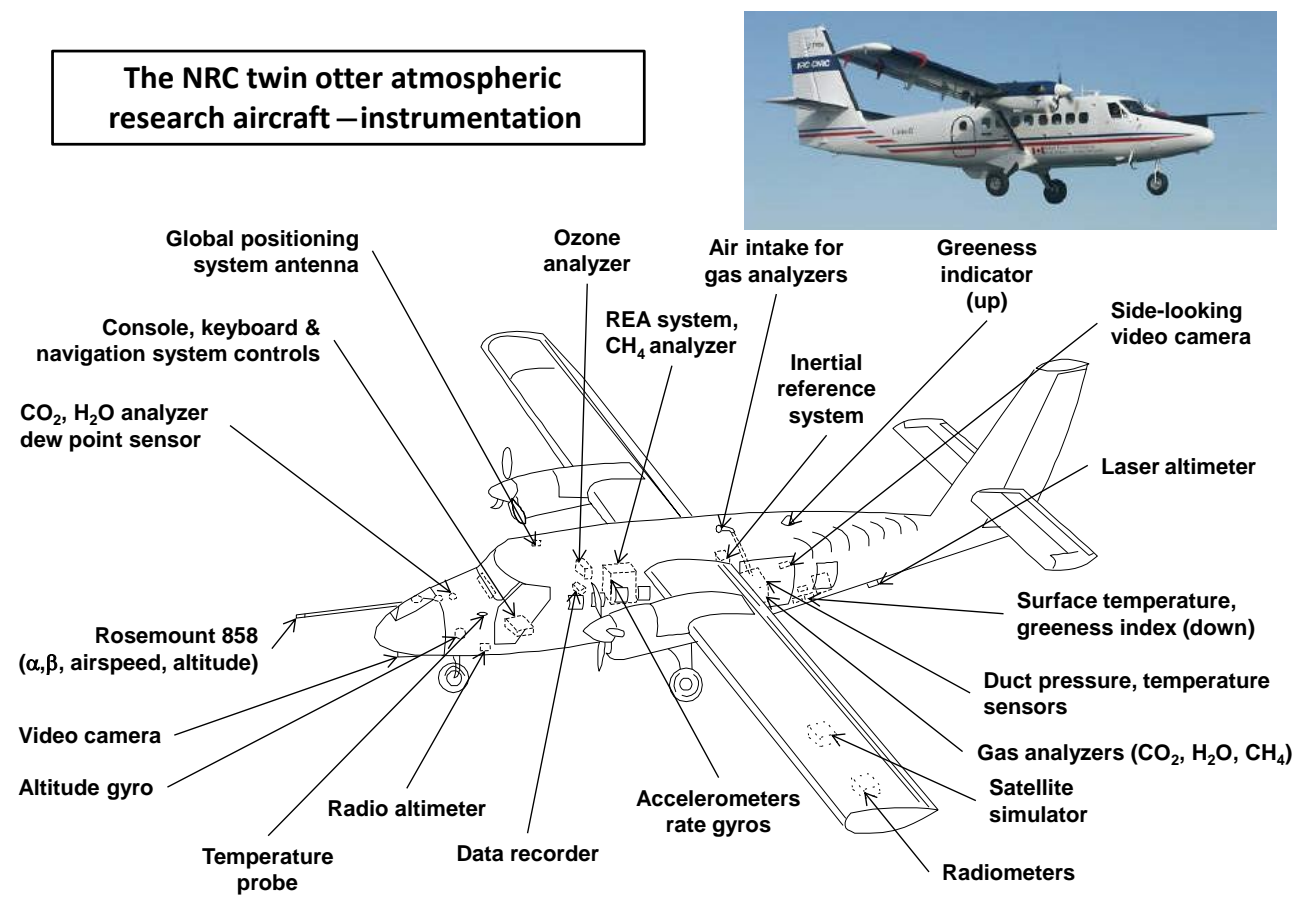

Figure 1. Instrumentation on-board the NRC Twin Otter, 1987-2011. Actual instrumentation varied slightly by measurement campaign.

projects, the fluxes of trace gases with very low atmospheric concentrations (e.g. $\mathrm{N}_{2} \mathrm{O}, \mathrm{CH}_{4}$ ), were measured using the Relaxed Eddy Accumulation (REA) technique (Pattey et al., 2006). Details on the aircraft, the instrumentation and various sampling strategies are presented in Desjardins et al. (2000).

\section{Summary of measurements campaigns and their significant findings}

The Twin Otter Flux Data Archive presently available contains data from eight flux projects flown from 1987 to 2011 (Fig. 2 and Table 1). A short description of each project with a sample of some of the interesting findings follows.

\subsection{The First ISLSCP Field Experiment (FIFE)}

The First ISLSCP (International Satellite Land Surface Climatology Project) Field Experiment, carried out in Kansas, was designed to obtain satellite and ground observations for the development and validation of models relating surface fluxes to spectral data. An overview of FIFE was published by Sellers et al. (1992). The Twin Otter participated in four intensive field campaigns. Three campaigns took place in 1987 and one in 1989. Grid flights were shown to be an excellent way to document the spatial differences in mass and energy exchange associated with the FIFE site (Desjardins et al., 1992). Budget analysis of the boundary layer using grid flight and double-stack patterns (Betts et al., 1990, 1992) revealed an underestimation of the sensible and latent heat

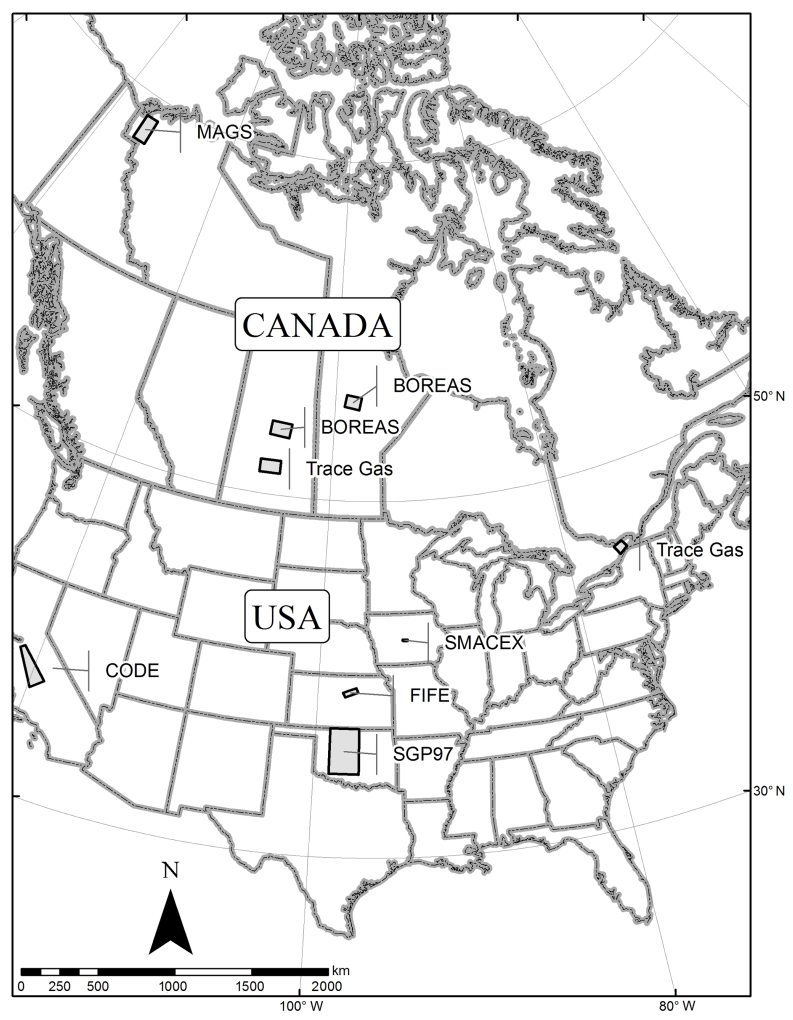

Figure 2. Location of measurement campaigns flown by the NRC Twin Otter, 1987-2011. 
Table 1. Summary of NRC Twin Otter measurement campaigns, 1987-2011.

\begin{tabular}{|c|c|c|c|c|c|c|c|c|c|}
\hline \# & Campaign & Location & Year & Dates & Landcover types & $\begin{array}{l}\text { Project } \\
\text { flights }\end{array}$ & $\begin{array}{l}\text { Project } \\
\text { flight } \\
\text { hours }\end{array}$ & $\begin{array}{l}\text { Measured } \\
\text { fluxes }^{\mathrm{a}}\end{array}$ & $\begin{array}{l}\text { Flight patterns (Typical } \\
\text { altitude, m a.g.l.) }\end{array}$ \\
\hline 1 & FIFE & Central Kansas, USA & 1987 & $\begin{array}{l}26 \text { Jun- } \\
16 \text { Oct }\end{array}$ & $\begin{array}{l}\text { Mixed agriculture; } \\
\text { grassland }\end{array}$ & 42 & 103 & $\begin{array}{l}U W, H \\
L E, \mathrm{CO}_{2}\end{array}$ & $\begin{array}{l}\text { Line (variable), stack (vari- } \\
\text { ous } 90-750), L \text { pattern ( } 90 \text {, } \\
180,270) \text {, } \\
\text { grid }(90) \text {, sounding (near } \\
\text { surface - max. 2500), re- } \\
\text { gional }(150)\end{array}$ \\
\hline 1 & FIFE & Central Kansas, USA & 1989 & $\begin{array}{l}27 \text { Jul- } \\
12 \text { August }\end{array}$ & $\begin{array}{l}\text { Mixed agriculture; } \\
\text { grassland }\end{array}$ & 16 & 69 & $\begin{array}{l}U W, H \\
L E, \mathrm{CO}_{2}\end{array}$ & $\begin{array}{l}\text { Line (variable), stack (var- } \\
\text { ious } 90-1300), L \text { pattern } \\
(50,180,270) \text {, } \\
\text { grid }(90) \text {, sounding (near } \\
\text { surface - max. 2500), re- } \\
\text { gional }(150)\end{array}$ \\
\hline 2 & CODE & $\begin{array}{l}\text { San Joaquin Valley, } \\
\text { USA }\end{array}$ & 1991 & $\begin{array}{l}10 \text { Jul- } \\
5 \text { August }\end{array}$ & $\begin{array}{l}\text { Mixed agriculture } \\
\text { (cotton, grapes, } \\
\text { orchards); grassland; } \\
\text { urban }\end{array}$ & 24 & 62 & $\begin{array}{l}U W, H \\
L E, \mathrm{CO}_{2} \\
\mathrm{O}_{3}\end{array}$ & $\begin{array}{l}\text { Line }(30,60) \text {, stack }(30, \\
60,90) \text {, grid }(30) \text {, sounding } \\
\text { (near surface - max. 2500), } \\
\text { regional }(150) \text {, city }(150)\end{array}$ \\
\hline 3 & BOREAS & $\begin{array}{l}\text { Southern and Northern } \\
\text { Study Areas of the } \\
\text { BOREAS project, } \\
\text { Saskatchewan and } \\
\text { Manitoba, Canada }\end{array}$ & 1994 & $\begin{array}{l}25 \text { May- } \\
19 \text { Sep }\end{array}$ & $\begin{array}{l}\text { Boreal forest; } \\
\text { mixed forest; mixed } \\
\text { agriculture (wheat, } \\
\text { canola, pasture); lakes }\end{array}$ & 57 & 154 & $\begin{array}{l}U W, H \\
L E, \mathrm{CO}_{2} \\
\mathrm{O}_{3}\end{array}$ & $\begin{array}{l}\text { Grid (30), Line (40), stack } \\
(40,100,170) \text {, sounding } \\
\text { (near surface - max. 2900), } \\
\text { regional (40) }\end{array}$ \\
\hline 3 & BOREAS & $\begin{array}{l}\text { Southern and Northern } \\
\text { Study Areas of the } \\
\text { BOREAS project, } \\
\text { Saskatchewan and } \\
\text { Manitoba, Canada }\end{array}$ & 1996 & $\begin{array}{l}9 \text { Jul- } \\
8 \text { August }\end{array}$ & $\begin{array}{l}\text { Boreal forest; } \\
\text { mixed forest; lakes }\end{array}$ & 27 & 64 & $\begin{array}{l}U W, H \\
L E, \mathrm{CO}_{2} \\
\mathrm{O}_{3}\end{array}$ & $\begin{array}{l}\text { Grid (30), Line (40), stack } \\
\text { (various 20-300), sounding } \\
\text { (near surface - max. 2900), } \\
\text { regional (40) }\end{array}$ \\
\hline 4 & SGP97 & Oklahoma, USA & 1997 & $\begin{array}{l}18 \text { Jun- } \\
17 \text { Jul }\end{array}$ & $\begin{array}{l}\text { Mixed agriculture } \\
\text { (pasture, wheat, other } \\
\text { crops); tallgrass prairie }\end{array}$ & 27 & 83 & $\begin{array}{l}U W, H \\
L E, \mathrm{CO}_{2} \\
\mathrm{O}_{3}\end{array}$ & $\begin{array}{l}\text { Line }(40) \text {, stack }(40,100 \text {, } \\
170) \text {, sounding (near sur- } \\
\text { face - max. 2900), regional } \\
(40)\end{array}$ \\
\hline 5 & MAGS & $\begin{array}{l}\text { Mackenzie River delta, } \\
\text { Northwest Territories, } \\
\text { Canada }\end{array}$ & 1999 & $\begin{array}{l}21 \text { May- } \\
14 \text { Jul }\end{array}$ & $\begin{array}{l}\text { Boreal forest; } \\
\text { river delta }\end{array}$ & 24 & 70 & $\begin{array}{l}U W, H \\
L E, \mathrm{CO}_{2} \\
\mathrm{O}_{3}\end{array}$ & $\begin{array}{l}\text { Line (65), stack }(30,60 \text {, } \\
90) \text {, grid (65), regional }(65) \text {, } \\
\text { sounding (near surface - } \\
\text { max. 2200) }\end{array}$ \\
\hline 6 & $\begin{array}{l}\text { Trace Gas - } \\
\mathrm{N}_{2} \mathrm{O}\end{array}$ & $\begin{array}{l}\text { Southeastern Ontario, } \\
\text { Canada }\end{array}$ & 2000 & $\begin{array}{l}21 \mathrm{Mar}- \\
10 \mathrm{Apr}\end{array}$ & $\begin{array}{l}\text { Mixed agricultural } \\
\text { (corn, soybean); mixed } \\
\text { forest }\end{array}$ & 6 & 10 & $\begin{array}{l}U W, \mathrm{H} \\
L E, \mathrm{CO}_{2} \\
\mathrm{O}_{3}, \mathrm{~N}_{2} \mathrm{O} \\
\text { (REA) }\end{array}$ & Line (65) \\
\hline 6 & $\begin{array}{l}\text { Trace Gas - } \\
\mathrm{N}_{2} \mathrm{O}\end{array}$ & $\begin{array}{l}\text { Southeastern Ontario, } \\
\text { Canada }\end{array}$ & 2001 & $\begin{array}{l}19 \text { Mar- } \\
27 \mathrm{Apr}\end{array}$ & $\begin{array}{l}\text { Mixed agricultural } \\
\text { (corn, soybean); mixed } \\
\text { forest }\end{array}$ & 14 & 20 & $\begin{array}{l}U W, \mathrm{H}, \\
L E, \mathrm{CO}_{2} \\
\mathrm{O}_{3}, \mathrm{~N}_{2} \mathrm{O} \\
\text { (REA) }\end{array}$ & Line (65) \\
\hline 6 & $\begin{array}{l}\text { Trace Gas - } \\
\mathrm{N}_{2} \mathrm{O}\end{array}$ & $\begin{array}{l}\text { Southern } \\
\text { Saskatchewan, Canada }\end{array}$ & 2002 & 2-17 Apr & $\begin{array}{l}\text { Mixed agriculture } \\
\text { (mixed grains, canola, } \\
\text { pulses, forage/pasture) }\end{array}$ & 13 & 20 & $\begin{array}{l}U W, \mathrm{H} \\
L E, \mathrm{CO}_{2} \\
\mathrm{O}_{3}, \mathrm{~N}_{2} \mathrm{O} \\
\text { (REA) }\end{array}$ & Line (60) \\
\hline 7 & SMACEX & $\begin{array}{l}\text { Walnut Creek Water- } \\
\text { shed, Iowa, USA }\end{array}$ & 2002 & $\begin{array}{l}15 \text { Jun- } \\
6 \text { Jul }\end{array}$ & $\begin{array}{l}\text { Mixed agriculture } \\
\text { (corn, soybean) }\end{array}$ & 16 & 46 & $\begin{array}{l}U W, H \\
L E, \mathrm{CO}_{2} \\
\mathrm{O}_{3}\end{array}$ & $\begin{array}{l}\text { Line (40), sounding (near } \\
\text { surface - max. 2000) }\end{array}$ \\
\hline 6 & $\begin{array}{l}\text { Trace Gas - } \\
\mathrm{N}_{2} \mathrm{O}\end{array}$ & $\begin{array}{l}\text { Southeastern Ontario, } \\
\text { Canada }\end{array}$ & 2003 & $\begin{array}{l}26 \text { Mar- } \\
8 \text { Oct }\end{array}$ & $\begin{array}{l}\text { Mixed agricultural } \\
\text { (corn, soybean); mixed } \\
\text { forest }\end{array}$ & 31 & 49 & $\begin{array}{l}U W, \mathrm{H} \\
L E, \mathrm{CO}_{2} \\
\mathrm{O}_{3}, \mathrm{~N}_{2} \mathrm{O} \\
\text { (REA) }\end{array}$ & Line (65) \\
\hline 6 & $\begin{array}{l}\text { Trace Gas - } \\
\mathrm{N}_{2} \mathrm{O}\end{array}$ & $\begin{array}{l}\text { Southeastern Ontario, } \\
\text { Canada }\end{array}$ & 2004 & $\begin{array}{l}29 \text { Mar- } \\
4 \text { Jun }\end{array}$ & $\begin{array}{l}\text { Mixed agricultural } \\
\text { (corn, soybean); mixed } \\
\text { forest }\end{array}$ & 21 & 30 & $\begin{array}{l}U W, H \\
L E, \mathrm{CO}_{2} \\
\mathrm{O}_{3}, \mathrm{~N}_{2} \mathrm{O} \\
\text { (REA) }\end{array}$ & Line (55) \\
\hline 8 & $\begin{array}{l}\text { Trace Gas - } \\
\mathrm{CH}_{4}\end{array}$ & $\begin{array}{l}\text { Southeastern Ontario, } \\
\text { Canada }\end{array}$ & 2011 & $\begin{array}{l}8 \text { Apr- } \\
10 \text { May }\end{array}$ & $\begin{array}{l}\text { Mixed agricultural } \\
\text { (corn, soybean); mixed } \\
\text { forest; urban; wetland }\end{array}$ & 10 & 15 & $\begin{array}{l}U W, H \\
L E, \mathrm{CO}_{2} \\
\mathrm{CH}_{4}\end{array}$ & $\begin{array}{l}\text { Line (170), stack }(150,200 \text {, } \\
250) \text {, sounding (near sur- } \\
\text { face - max. } 2000)\end{array}$ \\
\hline
\end{tabular}

${ }^{a} U W$, momentum; $H$, sensible heat; $L E$, latent heat; $\mathrm{CO}_{2}$, carbon dioxide; $\mathrm{O}_{3}$, ozone; $\mathrm{N}_{2} \mathrm{O}$, nitrous oxide; $\mathrm{CH}_{4}$, methane. 
ranging from 20 to $30 \%$ based on energy balance considerations. Some of the underestimation was attributed to the short length of the flight tracks and the high-pass filtering of the data, which was done to minimize the impact of nonstationarity on flux measurements. Both factors are known to contribute to the non-closure of the energy budget, which is an ongoing challenge warranting further research (Eder et al., 2014; Mauder et al., 2007).

\subsection{The California Ozone Deposition Experiment (CODE)}

In the summer of 1991 the San Joaquin Valley Air Pollution Study Agency organized a 4-week international field experiment to measure ozone concentrations and fluxes in the San Joaquin Valley of California (Pederson et al., 1995). The objective was to improve the understanding of the exchange processes occurring between the atmosphere and various types of vegetation. Ozone deposition velocities were shown to have a high correlation with Normalized Difference Vegetation Index (NDVI) for all the major crops. With knowledge of the mean ozone concentration, this relationship can then be used in conjunction with satellite data to estimate the amount of ozone absorbed by crops (Desjardins et al., 1999). Mahrt et al. (1994) used repeated runs over the same track for the partial isolation of the influence of surface heterogeneity and transient mesoscale motion. Such transfer can best be quantified using aircraft-based measurements. The versatility of aircraft-based flux measurements was demonstrated by showing the change in the $\mathrm{O}_{3}$ concentration and flux upwind and downwind of a major highway (Guo et al., 1995) and by showing the magnitude of the $\mathrm{CO}_{2}$ concentration and flux at an altitude of $150 \mathrm{~m}$ above the city of Fresno (Desjardins et al., 2000).

\subsection{The Boreal Ecosystem Atmosphere Study (BOREAS)}

The Boreal Ecosystem Atmosphere Study (BOREAS) was a large international field and analysis campaign organized by the NASA Goddard Space Flight Centre (Sellers et al., 1997). It was designed to improve the understanding of the interactions between the Boreal Forest biome and the atmosphere. The experiment focussed on two study areas in the boreal forest region of Canada, one north of Prince Albert, Saskatchewan, and the other near Thompson, Manitoba. Several well-instrumented towers measured fluxes and supporting meteorological and radiative data over the main forest types in the two study areas. The Twin Otter flew three flight campaigns in 1994 and one in 1996. Sun et al. (1997) showed that at night, lake induced atmospheric circulation resulted in venting of $\mathrm{CO}_{2}$ over the lake. This meant that the $\mathrm{CO}_{2}$ flux could not be accurately measured over the forest at night by tower-based systems in close proximity to the lake. Chen et al. (1999) used the combination of land cover informa- tion and tower-based flux measurements to obtain flux estimates that could be compared to those obtained by flying a grid pattern $15 \mathrm{~km}$ by $15 \mathrm{~km}$. Mauder et al. (2007) used Wavelet analysis on airborne flux measurements to investigate thermally induced mesoscale circulations and turbulent organized structures. According to independent large eddy simulation studies, these are considered as a major contributor to the energy budget non-closure problem. Their results put in question the practice of correcting eddy covariance measurements of the sensible and the latent heat flux for the lack of energy budget closure according to the Bowen ratio and of correcting carbon dioxide fluxes according to the energy balance residual.

\subsection{Southern Great Plains (SGP97)}

The Southern Great Plains 1997 (SGP97) Hydrology Experiment was motivated by the widespread interest among hydrologists, soil scientists and meteorologists in the problems of estimating soil moisture and temperature states at the continental scale, and their coupling to the atmosphere (Jackson et al., 1999). The main objective was to develop algorithms using remotely sensed microwave data to measure soil moisture at scales expected from future satellite-based microwave systems. Use of both the airborne thermal and microwave imagery collected during SGP97 along with tower and aircraft flux measurements spawned the development and validation of remote sensing-based land surface schemes for water, energy and carbon flux estimation largely based on the twosource energy balance (TSEB) modelling framework (Norman et al., 1995). Kustas et al. (2006) used corresponding flux field outputs from the Atmosphere-Land Exchange Inverse (ALEXI) and the disaggregated ALEXI model (Anderson et al., 2011) in combination with tower and aircraftbased flux measurements to investigate flux-footprint relations (Schuepp et al., 1990). With techniques like Wavelet analysis, which can provide the full flux contribution over distances as short as $100 \mathrm{~m}$, these data lend themselves to additional studies such as combining satellite and aircraft spectral data with aircraft-based flux measurements.

\subsection{Mackenzie GEWEX Study (MAGS)}

The Mackenzie GEWEX Study (MAGS) was part of the Global Energy and Water Cycle Experiment (GEWEX). MAGS was a comprehensive study of the hydrologic cycle and energy fluxes of the Mackenzie River Basin, which is the largest North American source of fresh water to the Arctic Ocean. The role of the NRC Twin Otter atmospheric research aircraft in MAGS was to provide measurements of surface-atmosphere exchange of sensible and latent heat and $\mathrm{CO}_{2}$ at temporal and spatial scales suitable for model testing. Mauder et al. (2008) used these data to demonstrate that flux measurements from a low-flying aircraft could be used to produce 2-dimensional maps of the sensible and latent heat 
flux for this complex ecosystem. Recent work has demonstrated how aircraft-based flux data can be used in combination with satellite-based input data to develop environmental response functions (Metzger et al., 2013). These permit an order-of-magnitude increase in spatio-temporal resolution and extend the resulting flux maps.

\subsection{Soil Moisture-Atmosphere Coupling Experiment (SMACEX)}

The Soil Moisture-Atmosphere Coupling Experiment (SMACEX) was conducted over the period from 15 June to 6 July 2002 over the Walnut Creek Watershed near Ames, Iowa a corn and soybean production area (Kustas et al., 2005). The data collected in SMACEX represent a relatively wide range of atmospheric, soil moisture, and vegetation states for use in modeling studies. This unique dataset consists of tower and aircraft flux measurements of heat, water vapour, momentum, carbon dioxide and ozone. It was collected simultaneously with a wide range of satellite data in order to develop satellite-based algorithms for land surface flux estimation. These algorithms were evaluated against the network of flux towers, and should in the future be compared with the aircraft-flux and regional remote sensing-based models such as ALEXI. Finally the relatively dense network of flux towers located in the experimental domain of corn and soybean fields afforded a unique opportunity to compare aircraft and tower fluxes (Prueger et al., 2005). These results were preliminary and require a more rigorous suite of analyses. As the techniques for accurately estimating mass and energy fluxes using aircraft-based technology evolve, it is very likely that the accuracy of some of the land surface and remote sensing modeling algorithms will be improved. This should result in a better understanding of the atmospheric boundary layer and other non-local effects on flux tower measurements.

\subsection{Trace gas $-\mathrm{N}_{2} \mathrm{O}$}

From 2000 to 2004, the Twin Otter was flown in a series of flux-measuring studies to quantify $\mathrm{N}_{2} \mathrm{O}$ emissions. The objective was to utilize the REA system on the Twin Otter to measure the flux of $\mathrm{N}_{2} \mathrm{O}$ (Pattey et al., 2007). One project, which took place in Southern Saskatchewan, focussed on comparing the $\mathrm{N}_{2} \mathrm{O}$ emissions for a $10 \mathrm{~km}$ by $10 \mathrm{~km}$ area obtained using a large number of chambers to aircraft flux measurements by flying a grid pattern over the site (Pattey et al., 2007). A second project was carried out in Eastern Ontario along two $20 \mathrm{~km}$ transects (Desjardins et al., 2010). The measurements covered two periods when the $\mathrm{N}_{2} \mathrm{O}$ emissions from agricultural lands are at their greatest: the spring burst period associated with spring thaw and the period just after the application of $\mathrm{N}$ fertilizers in the spring. They showed that $\mathrm{N}_{2} \mathrm{O}$ emissions varied substantially from day-to-day but were very similar for the two agricultural areas $30 \mathrm{~km}$ apart.
The day-to-day difference between the aircraft-based flux measurements and estimates by the Denitrification and Decomposition (DNDC) model ( $\mathrm{Li}, 2000)$ confirmed that the $25 \%$ estimate commonly assumed for the indirect $\mathrm{N}_{2} \mathrm{O}$ emissions as part of the IPCC methodology is reasonable (Desjardins et al., 2010).

\subsection{Trace gas $-\mathrm{CH}_{4}$}

In 2011, $\mathrm{CH}_{4}$ flux measurements were collected over an agricultural region in eastern Canada in order to verify $\mathrm{CH}_{4}$ inventory from agricultural sources. A fast response $\mathrm{CH}_{4}$ analyzer and a REA system were flown along several $20 \mathrm{~km}$ transects at an altitude of $60 \mathrm{~m}$. This study showed that similar methane fluxes can now be obtained using the REA and the eddy covariance techniques using the available instrumentation. It also demonstrated that in many agricultural regions, there can be other important sources of methane beside livestock such as wetlands and waste water treatment plants, that act as large and confounding sources of methane (Desjardins et al., 2016).

\section{Conclusions}

This publication documents the availability of archived data from Twin Otter flux projects flown from 1987 to 2011. The archive includes files of time series of a large selection of variables stored at either $16 \mathrm{~Hz}$ (1987 to 1994$)$ or $32 \mathrm{~Hz}$ (1996 to 2011). Most of these projects were conducted in collaboration with scientists from universities and other research agencies. The archive represents high-quality data from over 4000 flux runs flown over a wide range of landscapes. It is a resource that could be used to extend the scientific knowledge and the considerable body of literature already generated by these projects. During these studies, three flux measurements were calculated: raw, detrended and high-pass filtered. This was done as an attempt to deal with conditions of non-stationarity. It now appears that time-frequency analyses such as Wavelets might be a more effective way to deal with this condition. We have started redoing some of the analyses but it is only one example of the new type of analysis that can be done with these data. The development of environmental response functions using the data collected during these projects could greatly improve the value of satellite data for assessing crop conditions. Clearly these large scale, interdisciplinary field studies have greatly advanced thermalbased energy balance modeling schemes for reliable field to regional scale energy balance modeling (Kustas and Anderson, 2009). Utilizing these flux-aircraft measurements should provide greater insight to the accuracy of the predicted flux fields generated using satellite-based algorithms. 
The works published in this journal are distributed under the Creative Commons Attribution 3.0 License. This license does not affect the Crown copyright work, which is re-usable under the Open Government Licence (OGL). The Creative Commons Attribution 3.0 License and the OGL are interoperable and do not conflict with, reduce or limit each other.

\section{${ }^{\odot}$ Crown copyright 2016}

Acknowledgements. Funding agencies, organizers of large scale experiments such as P. Sellers, F. Hall, J. Pederson, T. Jackson, W. Kustas, R. Stewart and all the collaborators and PhD students who have contributed to these projects are gratefully acknowledged. We also thank R. W. A. Hutjes, S. Metzger and one anonymous reviewer for constructive criticism to improve this manuscript.

Edited by: F. C. Bosveld

Reviewed by: S. Metzger, R. W. A. Hutjes, and one anonymous referee

\section{References}

Anderson, M. C., Kustas, W. P., Norman, J. M., Hain, C. R., Mecikalski, J. R., Schultz, L., González-Dugo, M. P., Cammalleri, C., d'Urso, G., Pimstein, A., and Gao, F.: Mapping daily evapotranspiration at field to continental scales using geostationary and polar orbiting satellite imagery, Hydrol. Earth Syst. Sci., 15, 223-239, doi:10.5194/hess-15-223-2011, 2011.

Betts, A. K., Desjardins, R. L., MacPherson, J. I., and Kelly, R. D.: Boundary-layer heat and moisture budgets from FIFE, Bound.Lay. Meteorol., 50, 109-138, 1990.

Betts, A. K., Desjardins, R. L., and MacPherson, J. I.: Budget analysis of the boundary layer grid flights during FIFE 1987, J. Geophys. Res., 97, 18533-18546, 1992.

Chen, J. M., Leblanc, S. G., Cihlar, J., Desjardins, R. L., and MacPherson, J. I.: Extending aircraft- and tower-based $\mathrm{CO}_{2}$ flux measurements to a boreal region using a Landsat thematic mapper land cover map, J. Geophys. Res., 104, 16859-16877, 1999.

Desjardins, R. L. and MacPherson, J. I.: Water vapour flux measurements from aircraft, in: Land Surface Evaporation: Measurement and Parameterization, edited by: Schmugge, T. and André, J. C., Springer-Verlag Ltd, New York, NY, USA, 245-260, 1991.

Desjardins, R. L., Brach, E. J., Alvo, P., and Schuepp, P. H.: Aircraft monitoring of surface carbon dioxide exchange, Science, 216, 733-735, 1982.

Desjardins, R. L., Schuepp, P. H., MacPherson, J. I., and Buckley, D. J.: Spatial and temporal variations of the fluxes of carbon dioxide and sensible and latent heat over the FIFE site, J. Geophys. Res., 97, 18467-18475, doi:10.1029/92JD01089, 1992.

Desjardins, R. L., MacPherson, J. I., and Schuepp, P. H.: Ground truthing for satellites using aircraft-based flux measurements, Proceedings of the International Symposium on Applied Agrometeorology and Agroclimatology, Volos, Greece, 24-26 April 1996, 53-59, 1999.

Desjardins, R. L., MacPherson, I., and Schuepp, P. H.: Aircraftbased flux sampling strategies, in: Encyclopedia of Analytical
Chemistry, edited by: Meyers, R. A., John Wiley and Sons Ltd., Chichester, UK, 3573-3588, 2000.

Desjardins, R. L., Pattey, E., Smith, W. N., Worth, D., Grant, B. B., Srinivasan, R., MacPherson, I. J., and Mauder, M.: Multiscale estimates of $\mathrm{N}_{2} \mathrm{O}$ emissions from agricultural lands, Agr. Forest Meteorol., 150, 817-824, doi:10.1016/j.agrformet.2009.09.001, 2010.

Desjardins, R. L., Worth, D. E., Srinivasan, R., Pattey, E., VanderZaag, A. C., Mauder, M., Metzger, S., Worthy, D., and Sweeney, C.: Verifying Inventory Estimates of Agricultural Methane Emissions at a Regional Scale Using Aircraft-Based Flux Measurements, in preparation, 2016.

Eder, F., De Roo, F., HKohnert, K., Desjardins, R. L., Schmid, H. P., and Mauder, M.: Evaluation of two energy balance closure parameterizations, Bound.-Lay. Meteorol., 151, 195-219, doi:10.1007/s10546-013-9904-0, 2014.

Guo, Y., Desjardins, R. L., MacPherson, J. I., and Schuepp, P. H.: A simple scheme for partitioning aircraft-measured ozone fluxes into surface-uptake and chemical transformation, Atmos. Environ., 29, 3199-3207, doi:10.1016/1352-2310(95)00088-G, 1995.

Jackson, T. J., Le Vine, D. M., Hsu, A. Y., Oldak, A., Starks, P. J., Swift, C. T., Isham, J. D., and Haken, M.: Soil moisture mapping at regional scales using microwave radiometry: The Southern Great Plains Hydrology Experiment, IEEE T. Geosci. Remote Sens., 37, 2136-2151, 1999.

Kustas, W. P. and Anderson, M. C.: Advances in thermal infrared remote sensing for land surface modeling, Agr. Forest Meteorol., 149, 2071-2081, 2009.

Kustas, W. P., Hatfield, J. L., and Prueger, J. H.: The Soil MoistureAtmosphere Coupling Experiment (SMACEX): Background, Hydrometeorological Conditions, and Preliminary Findings, J. Hydrometeorol., 6, 791-804, 2005.

Kustas, W. P., Anderson, M. C., French, A. N., and Vickers, D.: Using a remote sensing field experiment to investigate fluxfootprint relations and flux sampling distributions for tower and aircraft-based observations, Adv. Water Resour., 29, 355-368, doi:10.1016/j.advwatres.2005.05.003, 2006.

Li, C.: Modeling trace gas emissions from agricultural ecosystems, Nutr. Cycl, Agroecosys., 58, 259-276, 2000.

MacPherson, J. I. and Bastian, M.: Archive of NRC Twin Otter Data From the 1991-2003 Flux Projects, National Research Council Canada, Institute for Aerospace Research, Ottawa, Ontario, Canada, Report LTR-FR-204, 16 pp., 2003.

Mahrt, L., MacPherson, J. I., and Desjardins, R.: Observations of fluxes over heterogeneous surfaces, Bound.-Lay. Meteorol., 67, 345-367, 1994.

Mauder, M., Desjardins, R. L., and MacPherson, J. I.: Scale analysis of airborne flux measurements over heterogeneous terrain in a boreal ecosystem, J. Geophys. Res., 112, D13112, doi:10.1029/2006JD008133, 2007.

Mauder, M., Desjardins, R. L., and MacPherson, I. J.: Creating surface flux maps from airborne measurements: Application to the Mackenzie area GEWEX study MAGS 1999, Bound.-Lay. Meteorol., 129, 431-450, 2008.

Metzger, S., Junkermann, W., Mauder, M., Butterbach-Bahl, K., Trancón y Widemann, B., Neidl, F., Schäfer, K., Wieneke, S., Zheng, X. H., Schmid, H. P., and Foken, T.: Spatially explicit regionalization of airborne flux measurements using envi- 
ronmental response functions, Biogeosciences, 10, 2193-2217, doi:10.5194/bg-10-2193-2013, 2013.

Norman, J. M., Kustas, W. P., and Humes, K. S.: A two-source approach for estimating soil and vegetation energy fluxes in observations of directional radiometric surface temperature, Agr. Forest Meteorol., 77, 263-293, 1995.

Pattey, E., Edwards, G., Strachan, I. B., Desjardins, R. L., Kaharabata, S., and Wagner Riddle, C.: Towards standards for measuring greenhouse gas fluxes from agricultural fields using instrumented towers, Can. J. Soil Sci., 86, 373-400, 2006.

Pattey, E., Edwards, G. C., Desjardins, R. L., Pennock, D. J., Smith, W., Grant, B., and MacPherson, J. I.: Tools for quantifying $\mathrm{N}_{2} \mathrm{O}$ emissions from agroecosystems, Agr. Forest Meteorol., 142, 103-119, 2007.

Pederson, J. R., Massman, W. J., Mahrt, L., Delany, A., Oncley, S., Hartog, G. D., Neumann, H. H., Mickle, R. E., Shaw, R. H., Paw U, K. T., Grantz, D. A., MacPherson, J. I., and Desjardins, R.: California ozone deposition experiment: Methods, results, and opportunities, Atmos. Environ., 29, 3115-3132, 1995.

Prueger, J. H., Hatfield, J. L., Kustas, W. P., Hipps, L. E., MacDonald, J. I., Neale, C. M. U., Eichinger, W. E., Cooper, D. I., and Parkin, T. B.: Tower and aircraft eddy covariance measurements of water vapor, energy and carbon dioxide fluxes during SMACEX, J. Hydrometeorol., 6, 954-960, 2005.
Schuepp, P. H., Leclerc, M. Y., MacPherson, J. I., and Desjardins, R. L.: Footprint prediction of scalar fluxes from analytical solutions of the diffusion equation, Bound.-Lay. Meteorol., 50, 355-373, 1990.

Sellers, P. J., Hall, F. G., Asrar, G., Strebel, D. E., and Murphy, R. E.: An overview of the First International Satellite Land Surface Climatology Project (ISLSCP) Field Experiment (FIFE), J. Geophys. Res., 97, 18345-18371, 1992.

Sellers, P. J., Hall, F. G., Kelly, R. D., Black, A., Baldocchi, D. D., Berry, J., Ryan, M., Ranson, K. J., Crill, P. M., Lettenmaier, D. P., Margolis, H., Cihlar, J., Newcomer, J., Fitzjarrald, D. R., Jarvis, P. G., Gower, S. T., Halliwell, D., Williams, D., Goodison, B., Wickland, D. E., and Guertin, F. E.: BOREAS in 1997: Experiment overview, scientific results, and future directions, J. Geophys. Res., 102, 28731-28769, 1997.

Stewart, R. E., Leighton, H. G., Marsh, P., Moore, G. W. K., Ritchie, H., Rouse, W. R., Soulis, E. D., Strong, G. S., Crawford, R. W. and Kochtubajda, B.: The Mackenzie GEWEX Study: The Water and Energy Cycles of a Major North American River Basisn, B. Am. Meteorol. Soc., 79, 2665-2683, 1998.

Sun, J., Lenschow, D. H., Mahrt, L., Crawford, T. L., Davis, K. J., Oncley, S. P., MacPherson, J. I., Wang, Q., Dobosy, R. J., and Desjardins, R. L.: Lake-induced atmospheric circulations during BOREAS, J. Geophys. Res., 102, 29155-29166, 1997. 